\title{
Body condition and energy density of juvenile streaked prochilod Prochilodus lineatus (Valenciennes, 1837) in a Neotropical floodplain
}

\author{
Daiany de Fátima Corbetta ${ }^{1}$, Ana Lúcia Veronezzi² and Evanilde Benedito ${ }^{3}$
}

\begin{abstract}
Variations in energetic density $\left(E_{\mathrm{D}}\right)$ and the relative condition factor $\left(K_{\mathrm{n}}\right)$ of juveniles of Prochilodus lineatus were investigated to identify whether these two variables respond similarly to environmental factors. We hypothesized that fluviometric levels in different sub-basins of the Upper Paraná River floodplain positively influence the $E_{\mathrm{D}}$ and $K_{\mathrm{n}}$ of juvenile fish. Temporally, the values of $E_{\mathrm{D}}$ and $K_{\mathrm{n}}$ were linked more directly to the dynamics of the flood pulses on the plain. Spatially, the lowest values of $E_{\mathrm{D}}$ and $K_{\mathrm{n}}$ were observed in the environment that was directly affected by the operation of dams, the sub-basin Paraná. Although the energy density and condition factor did not show similar results for juveniles in some of the analyses, the evaluation of both parameters provided a complementary tool and additional information that enabled a more accurate investigation of the temporal and spatial dynamic processes in this Neotropical floodplain. We conclude that water level variations in different sub-basins of the Upper Paraná River floodplain considerably affect the relative condition factor and energy status of $P$. lineatus. We suggest that the impacts of this modification should be mitigated or avoided in order to maintain fish stocks and promote ecosystem integrity.
\end{abstract}

Variações na densidade energética $\left(E_{\mathrm{D}}\right)$ e no fator de condição relativo $\left(K_{\mathrm{n}}\right)$ de juvenis de Prochilodus lineatus foram investigadas buscando identificar se estas duas variáveis respondem de forma semelhante aos fatores ambientais. Nossa hipótese é que o nível fluviométrico, em diferentes subsistemas da planície de inundação do alto rio Paraná, influencia positivamente o $E_{\mathrm{D}} \mathrm{e} K_{\mathrm{n}}$ de juvenis da espécie. Temporalmente, os valores de $E_{\mathrm{D}}$ e $K_{\mathrm{n}}$ estiveram relacionados mais diretamente a dinâmica de pulsos de inundação presente na planície. Espacialmente, os menores valores de $E_{\mathrm{D}}$ e $K_{\mathrm{n}}$ foram verificados no ambiente mais diretamente afetado pela operação das barragens, o subsistema Paraná. Apesar da densidade de energia e do fator de condição não demonstrarem resultados semelhantes para juvenis em algumas das análises, a avaliação de ambos os parâmetros forneceu uma ferramenta complementar e informações adicionais, que permitiu uma investigação mais detalhada dos processos dinâmicos temporais e espaciais nesta várzea neotropical. Conclui-se que a variação do nível de água, em diferentes subsistemas da planície de inundação do alto rio Paraná, afeta consideravelmente a condição corpórea e energética de $P$. lineatus. Nós sugerimos que impactos que modifiquem este efeito devem ser mitigados ou evitados para manter o estoque de peixes e promover a integridade do ecossistema.

Keywords: Condition Factor, Food web, Habitat, Impact, Paraná basin.

\section{Introduction}

Variations in water levels are the driving force behind the functioning and productivity of floodplains (Junk, 1989). Studies conducted in the Upper Paraná River floodplain have highlighted the key role of flood pulses in the interpretation of local processes (Thomaz et al., 2007; Agostinho et al., 2008; Leandrini et al., 2008; Roberto et al., 2009). The Paraná River basin is one of the largest watersheds in the world controlled by dams that affect floodplain functioning (Petrere Júnior., 1996; Neiff, 2001; Agostinho et al., 2008). The dams result in diversity loss and reduced catches of commercial fish, which are becoming serious issues for the locals. Therefore, it is important to obtain bio-ecological information to achieve the best management program for the Paraná River (Agostinho et al., 2008).

Although the studied area in this floodplain is the last dam-free stretch, it is under the influence of impoundments along the main channel of the basin. It also provides an important habitat for several commercial fishes, such as Pseudoplatystoma corruscans (Spix \& Agassiz, 1829), Hemisorubim platyrhynchos (Valenciennes, 1840) and Salminus brasiliensis (Cuvier, 1816) including

${ }^{1}$ COMCAP, Universidade Estadual de Maringá, Av. Colombo, 5790, 87020-900 Maringá, PR, Brazil. daianyfc@outlook.com (corresponding author)

${ }^{2}$ PGB, Universidade Estadual de Maringá, Av. Colombo, 5790, 87020-900 Maringá, PR, Brazil. alveronezzi@yahoo.com.br

${ }^{3}$ NUPELIA/PEA/PGB, Universidade Estadual de Maringá, Av. Colombo, 5790, 87020-900 Maringá, PR, Brazil. eva@nupelia.uem.br 
Prochilodus lineatus (Valenciennes, 1837) (Oliveira et al., 2015), also known as curimbatá, sábalo, streaked prochilod or locally as the curimba (Bayo \& Yuan, 1996; Graça \& Pavanelli, 2007; Froese \& Pauly, 2015). Prochilodus lineatus is one of the most abundant and widely distributed fish in the various river basins of South America (Godoy, 1975; Agostinho et al., 1993; Silvasundar et al., 2001; Agostinho et al., 2003; Hahn et al., 2004; Espínola et al., 2010). In the Upper Paraná River floodplain, P. lineatus is important for recreational, commercial and subsistence fishing (Agostinho et al., 2003). Prochilodus lineatus is dentrivorous with a diet largely consisting of sediment and detritus (Bayo \& Cordiviola de Yuan, 1996; Hahn et al., 1997) and is an important prey for piscivores (LuzAgostinho et al., 2008; Bozza \& Hahn, 2010).

Due to its contribution to the natural food chain, $P$. lineatus plays an important role in energy flow and nutrient cycling in ecosystem and community dynamics. Therefore, condition factor and the energy density of fish have been used as indicators of their physiological status (Dourado \& Benedito-Cecilio, 2005; Monteiro et al., 2007). The energy density allows the determination of whether consumed energy is allocated for growth, metabolic demands, waste loss and reproductive needs (Adams et al., 1982; Cui \& Wootton, 1988; Adams \& Breck, 1990). The condition factor quantifies the welfare of the fish, which can be indirectly related to stores of lipids and energy and allows a comparison of the condition of different specimens from the same sample, independent of length (Le Cren, 1951; Herbinger \& Friars, 1991; Santos et al., 2004; Froese, 2006).

In ecology, knowledge of the variations of energy flows has been recognized as essential in understanding the organization of ecosystems (Lindeman, 1942), and thus, energy accumulation and allocation patterns are critical for the ecological success of organisms (Saldanã \& Venables, 1983). The comprehension of energy density in Neotropical fish is one of the main issues in ecosystem ecology, especially when involving juveniles in natural environments. In this study, we investigated the variations of energy density and condition factor in P. lineatus. We hypothesized that fluviometric levels in different subbasins of the Upper Paraná River floodplain positively influence the condition factor and energy density of juveniles of this species of detritivorous fish. High water levels are predicted to contribute to a higher energy density and condition factor due to an allocthonous input into floodplain ecosystems, and this will be reflected in a correlation between the condition factor and energy density.

\section{Material and Methods}

The study area included a stretch of the Upper Paraná River floodplain located between Porto Primavera Dam and the beginning of the Itaipu Reservoir. This is the last long, undammed stretch of the Paraná River (approximately 200 $\mathrm{km}$ ) (Thomaz et al., 2004). The floodplain of the Upper Paraná River is influenced by reservoirs and other projects located along the Paraná River, which is the main channel of the basin, and is joined by several tributaries, especially the Baia and Ivinhema. The plain also contains floodplain lakes, which play a vital role as spawning grounds and nurseries for migratory species. Due to impoundments, these environments have disappeared or were negatively influenced by the channel of the Paraná River.

Sampling. Samplings were performed quarterly from June 2010 to March 2011. The Paraná River floodplain consists of three sub-basins: the Ivinhema sub-basin (22 47'59.64"S; 5332'21.30"W), which has no dams; the Paraná sub-basin $\left(22^{\circ} 45^{\prime} 39.96\right.$ ”S; 5315'7.44”W), which has a series of dams on its main channel, the Paraná River; and the Baia sub-basin (2243'23.16”S; 5317'25.50”W), which is affected by the Paraná River. Three to five sites were sampled at each sub-basin (Fig. 1).

Prochilodus lineatus were sampled using gill nets with different mesh sizes (from 2.4 to $8.0 \mathrm{~cm}$ ). Gills nets were exposed for $24 \mathrm{~h}$ and were inspected every $8 \mathrm{~h}$. All 272 collected specimens were anesthetized and killed (with Eugenol). Specimens of $P$. lineatus collected from the floodplain of the Upper Paraná River were deposited in the Museu de Peixes of NUPELIA (Núcleo de Pesquisas em Limnologia, Ictiologia e Aquicultura, Universidade Estadual de Maringá) (NUP 11092 - http://peixe.nupelia. uem.br/). The following biometric characteristics of the collected specimens were measured: standard length $\left(L_{\mathrm{S}}, \mathrm{cm}\right)$, total weight $\left(W_{\mathrm{T}} \mathrm{g}\right)$, sex, and stage of gonadal development according to the criteria proposed and adapted by Vazzoler (1996). Only immature specimens were considered in this study to avoid the effects of the gonadal developmental stage on the energetic density and condition factors (Dourado \& Benedito-Cecilio, 2005). According to Barbieri et al. (2000) and Suzuki et al. (2004), the male length were between 21.3 to $24.9 \mathrm{~cm}$ and females were between 24.0 to $25.0 \mathrm{~cm}$.

Muscle samples were obtained from the dorsal region to above the lateral line of each specimen. Collected samples were washed with distilled water and wrapped in aluminum foil, labeled and frozen. Subsequently, samples were dried in a forced-air oven $\left(60{ }^{\circ} \mathrm{C}, 48 \mathrm{~h}\right)$ and were ground to a fine powder with a ball mill.

The energy density $\left(\mathrm{E}_{D}\right)$ of these samples (measured as kilocalories per gram dry weight; kcal/g DW) was determined using an adiabatic bomb calorimeter (Parr 1261) at the Energy Ecology Laboratory of NUPELIA.

Spatial and temporal means of the limnological variables used in this study were obtained from the LongTerm Ecological Research/Brazilian National Council for Development (PELD/CNPq), the Laboratory of Basic Limnology of NUPELIA, at the same sampling times as those of the fish (Table 1). 


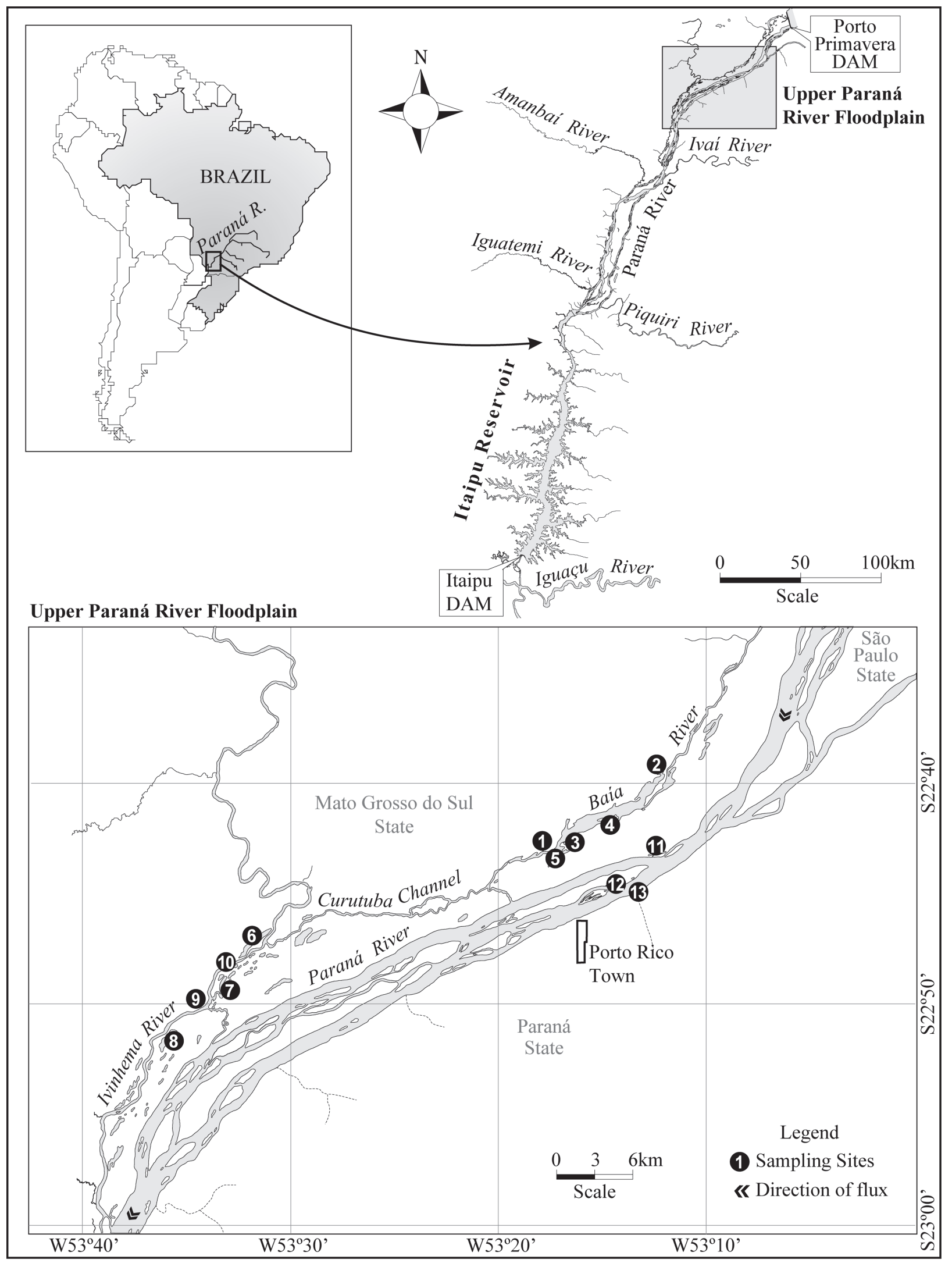

Fig. 1. Location of the sampling stations of Prochilodus lineatus on the Upper Paraná River floodplain, associated with the following sub-basins: Baia (5. Guaraná lagoon, 6. Gavião lagoon, 7. Fechada lagoon, 8. Pousada das Garças lagoon, 11. Baia River), Ivinhema (1. Finado Raimundo lagoon, 2. Patos lagoon, 3. Ventura lagoon, 4. Zé do Paco lagoon, 13. Ivinhema River) and Paraná (9. Garças lagoon, 10. Ressaco do Pau Veio, 12. Paraná River). 
Table 1. Mean values \pm SD of limnological variables for sub-basins and months sampled quarterly from June (Jun) 2010 to March (Mar) 2011: Ivi = Ivinhema, Bai = Baia, Par = Paraná, Alk = alkalinity $(\mathrm{mEq} / \mathrm{L}), \mathrm{Chl}=$ chlorophyll $(\mu \mathrm{g} / \mathrm{L}), \mathrm{Con}$ $=$ conductivity $(\mu \mathrm{S} / \mathrm{cm}), \mathrm{DO}=$ dissolved oxygen $(\mathrm{mg} / \mathrm{L}), \mathrm{TSM}=$ total suspended matter $(\mu \mathrm{g} / \mathrm{L}), \mathrm{OSM}=$ organic suspended matter $(\mathrm{mg} / \mathrm{L}), \mathrm{MSM}=$ mineral suspended matter $(\mathrm{mg} / \mathrm{L}), \mathrm{NH}_{4}=\operatorname{ammonia}(\mu \mathrm{g} / \mathrm{L}), \mathrm{NO}_{3}=$ nitrate $(\mu \mathrm{g} / \mathrm{L}), \mathrm{TN}=$ total nitrogen $(\mu \mathrm{g} / \mathrm{L}), \mathrm{PO}_{4}=$ phosphate $(\mu \mathrm{g} / \mathrm{L}), \mathrm{TP}=$ total phosphorus $(\mu \mathrm{g} / \mathrm{L}), \mathrm{Tem}=$ temperature $\left({ }^{\circ} \mathrm{C}\right)$, Turbidity $=$ Tub $(\mathrm{NTU})$. Different letters indicate significant differences $(\mathrm{p}<0.05)$.

\begin{tabular}{|c|c|c|c|c|c|c|c|}
\hline & \multicolumn{3}{|c|}{ Subsystems } & \multicolumn{4}{|c|}{ Months } \\
\hline & Ivi & Bai & Par & Jun & Sep & Dec & Mar \\
\hline Alk & $316^{a} \pm 58$ & $169^{b} \pm 103$ & $395^{\mathrm{a}} \pm 61$ & $223^{\mathrm{d}} \pm 153$ & $306^{b} \pm 119$ & $283^{\mathrm{ca}} \pm 124$ & $322^{a} \pm 37$ \\
\hline Chl & $10.1^{\mathrm{ab}} \pm 12.7$ & $8.8^{\mathrm{a}} \pm 7.0$ & $4.2^{b} \pm 5.6$ & $6.1 \pm 3.5$ & $16.0 \pm 15.4$ & $9.1 \pm 6.4$ & $2.2 \pm 1.0$ \\
\hline DO & $5.4 \pm 2.7$ & $5.8 \pm 1.8$ & $7.1 \pm 1.8$ & $7.1^{\mathrm{a}} \pm 1.8$ & $7.5^{\mathrm{a}} \pm 1.6$ & $4.4^{\mathrm{b}} \pm 1.7$ & $4.8^{b} \pm 2.5$ \\
\hline TSM & $2.0^{\mathrm{ab}} \pm 2.0$ & $1.3^{\mathrm{b}} \pm 0.5$ & $3.0^{\mathrm{a}} \pm 1.6$ & $2.2 \pm 1.6$ & $2.4 \pm 2.5$ & $1.6 \pm 1.0$ & $1.6 \pm 1.1$ \\
\hline $\mathrm{NH}_{4}$ & $8.9 \pm 6.0$ & $22.2 \pm 28.3$ & $21.0 \pm 30.6$ & $13.8^{b} \pm 27.1$ & $8.1^{b} \pm 7.9$ & $31.2^{\mathrm{a}} \pm 33.9$ & $13.1^{\mathrm{ab}} \pm 7.4$ \\
\hline $\mathrm{NO}_{3}$ & $24.0^{b} \pm 39$ & $17.7^{b} \pm 43$ & $144.6^{\mathrm{a}} \pm 73$ & $63.8 \pm 75.9$ & $36.8 \pm 54$ & $46.2 \pm 49$ & $58.0 \pm 104$ \\
\hline $\mathrm{TN}$ & $714^{b} \pm 166$ & $912^{\mathrm{a}} \pm 318$ & $679^{b} \pm 132$ & $827 \pm 254$ & $707 \pm 389$ & $795 \pm 151$ & $766 \pm 100$ \\
\hline $\mathrm{PO}_{4}$ & $8.9 \pm 5.6$ & $7.6 \pm 4.1$ & $8.7 \pm 4.7$ & $5.6^{\mathrm{ab}} \pm 1.9$ & $5.1^{\mathrm{a}} \pm 3.8$ & $8.32^{b} \pm 3.3$ & $14.0^{\mathrm{b}} \pm 3.8$ \\
\hline $\mathrm{TP}$ & $33.8^{\mathrm{a}} \pm 13$ & $46.1^{\mathrm{a}} \pm 25$ & $22.4^{\mathrm{b}} \pm 15$ & $28.3 \pm 15$ & $43.1 \pm 24$ & $47.45 \pm 22$ & $23.3 \pm 6$ \\
\hline
\end{tabular}

Study Design. Daily water levels were obtained from the Advanced Field Station of NUPELIA, in the municipality of Porto Rico, Paraná State. During samplings undertaken in 2010, the water level of the Paraná River was below $3.5 \mathrm{~m}$, above which is considered typical flooding conditions (Agostinho et al., 2004b; Thomaz et al., 2004). However, the water level rose above $3.5 \mathrm{~m}$ during the final sampling in March of 2011. Therefore, this final sampling was regarded as the beginning of flooding, while the others are considered from drought periods. It is noteworthy that the values of energy density and condition factors are the result of food resources obtained before the period in which the specimens were sampled. Thus, the results were considered in the analyses from the previous fluviometric data samplings (Fig. 2).

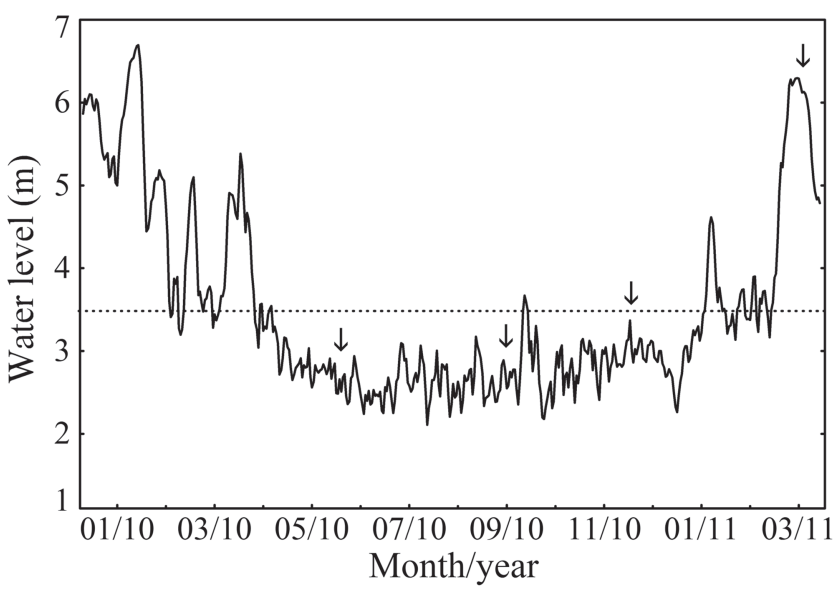

Fig. 2. Daily mean water levels of the Upper Paraná River. Arrows indicate sampling periods. Horizontal lines show the threshold of the water level for river-bank overflow $(350 \mathrm{~cm}$ = Paraná river, Agostinho et al., 2004b; Thomaz et al., 2004).
Data analysis. No significant differences were detected between the sexes, and therefore the data from all analyses were pooled. The length-weight relationship was estimated for pooled immature males and females, using the expression $W \mathrm{t}=a \times L \mathrm{~s}^{b}$, where $W \mathrm{t}=$ total weight, $L \mathrm{~s}=$ standard length, $a=$ intercept of the regression and $b=$ slope (Le Cren, 1951; Froese, 2006). The parameters $a$ and $b$ were high after logarithmic transformation of the data for weight and length and were, therefore, subjected to a subsequent adjustment of a straight line to the points for the Least-Squares Method (Vanzolini, 1993). Subsequently, the relative condition factor $\left(K_{\mathrm{n}}\right)$ was calculated as the ratio between the observed and expected weight for a given standard length $\left(K_{\mathrm{n}}=W \mathrm{t} /\right.$ $P \mathrm{e} ; P \mathrm{e}=$ calculated weight derived from length-weight relationship) (Le Cren, 1951).

To analyze temporal and spatial variations in the energy density $\left(E_{\mathrm{D}}\right)$ and relative condition factor $\left(K_{\mathrm{n}}\right)$, the sampled fish were grouped into two classes of standard length: Class 1 consisted of sizes between 13 and $16.4 \mathrm{~cm}$ and Class 2, between 16.5 and $20 \mathrm{~cm}$. The range of $L \mathrm{~s}$ was 13.0 to $20.0 \mathrm{~cm}$. The samples were grouped into classes to avoid interference of somatic growth on the analysis of the $K_{\mathrm{n}}$ (Garcia-Berthou, 2001) and $E_{\mathrm{D}}$ (Silva et al.,1999; Espínola et al., 2010). Significant differences in $E_{\mathrm{D}}$ values were calculated among the classes $(H=20.8$, d.f. $=1, P$ $<0.0001$ ), with the energy density of the fish increasing with fish length.

The assumptions of normality and homoscedasticity were not met; therefore, a nonparametric one-way analysis of variance (Kruskal-Wallis) was performed for each class of standard length, considering the values of $E_{\mathrm{D}}$ and $K_{\mathrm{n}}$, to identify significant differences in these 
values between months and the sub-basins sampled. Each site was considered as a replicate of a sub-basin (Block et al., 2001). The significance level was set at $\alpha=0.05$. $P$ values were subjected to Bonferroni correction after several statistical tests were performed simultaneously on a single data set (Zar, 1999).

Temporal and site variations on the limnological variables were analyzed through a one-way ANOVA without replication after $\log (\mathrm{x}+1)$ transformation, followed by Tukey's test (Sokal \& Rohlf, 1995). The level of significance adopted was 0.05 .

For limnological variables, a Principal Component Analysis (PCA) was performed to characterize the sampling months and sub-basins. We used $\log (x+1)$ transformation for the standardization of values in the PCA matrix, and significant axes for interpretation were selected using the broken-stick criterion. The scores of the retained axes were correlated (Spearman rank test) with the mean energy density and the mean relative condition factor for each sampling month and sub-basin. To measure how environmental variables influence the energy density and the condition factor, a multiple regression analysis between the original variable values was carried out in the selected Axis 1 of PCA for the medium energy density and condition factor.

The Spearman rank test $\left(r_{\mathrm{s}}\right)$ (Zar, 1999) was used to identify a potential correlation between the relative condition factor $\left(K_{\mathrm{n}}\right)$ and energy density $\left(E_{\mathrm{D}}\right)$, and between these parameters and standard length and total weight.

\section{Results}

Significant differences were not observed between the sexes of the 272 immature individuals of $P$. lineatus sampled in this study; therefore, the results presented are grouped for sex. The weight-length relationship with the pooled data of the immature $P$. lineatus males and females was $a=0.05$ and $b=2.81$. The equation of the fitted curve was $\log W \mathrm{t}=-1.31+2.81 \log L \mathrm{~s}\left(P<0.01, R^{2}\right.$ $=0.86)$ (Fig. 3).

The quarterly distribution of mean values of $E_{\mathrm{D}}$ and $K_{\mathrm{n}}$, grouped into size classes, showed significant differences only for $E_{\mathrm{D}}$ and $K_{\mathrm{n}}$ in Classes 2 [Fig. 3; (a): $H=7.18$, d.f. $=$ 2, $P=0.028$; (b): $H=39.41$, d.f. $=3, P<0.01$; (c): $H=1.56$, d.f. $=2, P=0.48$; (d): $H=17.12$, d.f. $=3, P<0.01]$. Thus, in the second class size, energy density values were higher in June than in September and December, whereas for the relative condition factor, smaller sizes were observed in March than in June and September (Fig. 4).

For the sub-basins, a significant difference was observed only in Class 1 for $K_{\mathrm{n}}$ [Fig. 4; (a): $H=12.66$, d.f. $=2, P<0.01$; (b): $H=12.15$, d.f. $=2, P<0.01$; (c): $H=3.25$, d.f. $=2, P=0.20$; (d): $H=19.25$, d.f. $=2, P<$ 0.01]. The highest values of $E_{\mathrm{D}}$ and $\mathrm{Kn}$ were observed in the Ivinhema sub-basin, and the Paraná sub-basin showed the lowest values (Fig. 5).
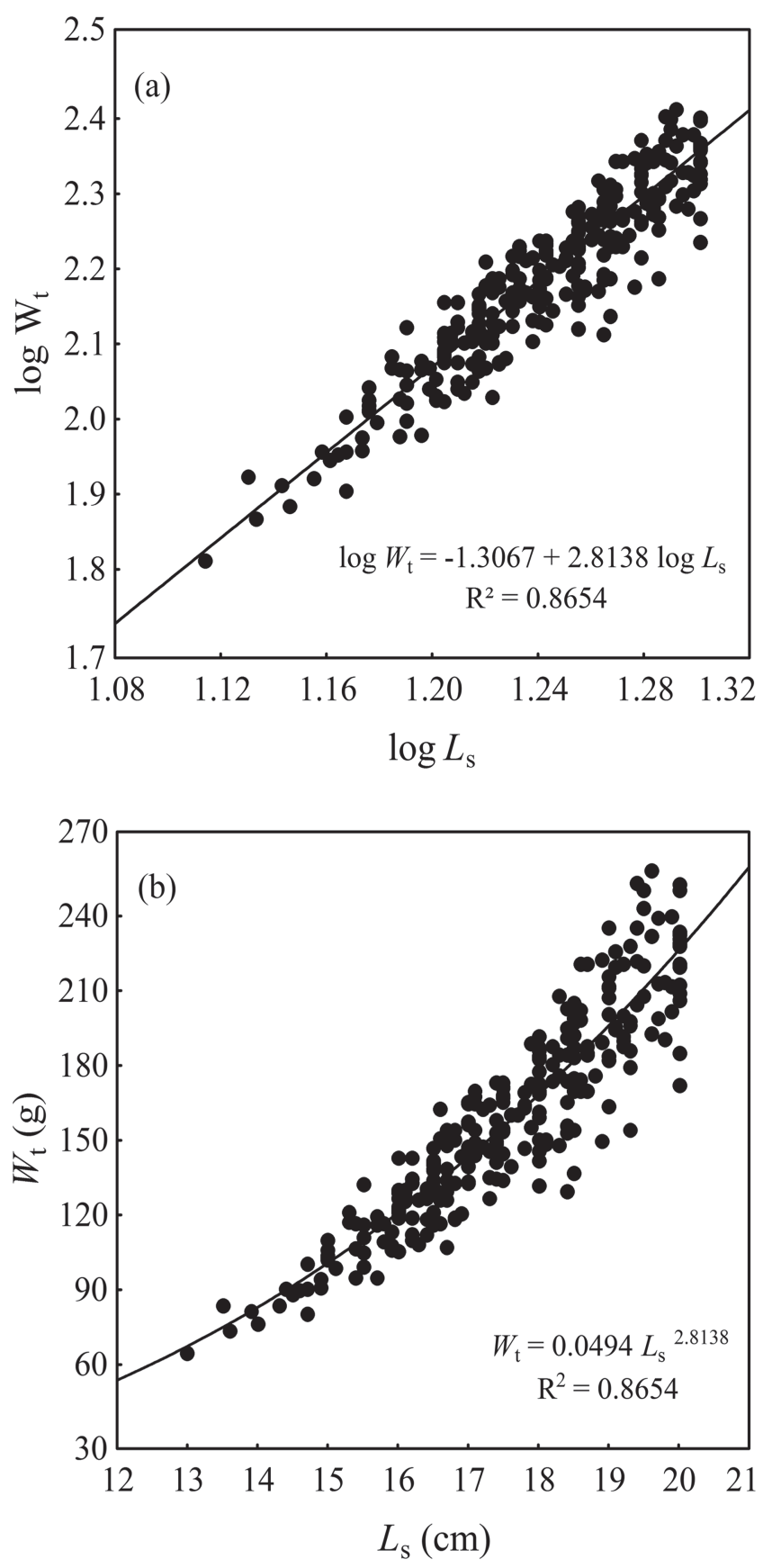

Fig. 3. Linear regression (a) and weight-length relationship (b) of juvenile Prochilodus lineatus in the floodplain of the Upper Paraná River.

Spatio-temporal analysis showed a different pattern among the variables analyzed. There were statistically significant variations among sites in turbidity $(\mathrm{F}=$ $3.86, \mathrm{P}=0.029)$, conductivity $(\mathrm{F}=85.61, \mathrm{P}<0.001)$, total suspended matter $(\mathrm{F}=4.08, \mathrm{P}=0.024)$, organic suspended matter $(\mathrm{F}=5.99, \mathrm{P}=0.005)$, alkalinity $(\mathrm{F}=$ $14.95, \mathrm{P}<0.001)$, chlorophyll $(\mathrm{F}=4.66, \mathrm{P}=0.015)$, total nitrogen $(\mathrm{F}=4.97, \mathrm{P}=0.012)$, phosphate $(\mathrm{F}=12.08, \mathrm{P}<$ $0.001)$ and total phosphorus $(\mathrm{F}=16.93, \mathrm{P}<0.001)$. Among months, turbidity $(\mathrm{F}=6.75, \mathrm{P}<0.001)$, water temperature 
$(\mathrm{F}=258.19, \mathrm{P}<0.001)$, dissolved oxygen $(\mathrm{F}=10.82$, $\mathrm{P}<0.001)$, organic suspended matter $(\mathrm{F}=3.29, \mathrm{P}=0.031)$, ammonia $(\mathrm{F}=4.72, \mathrm{P}=0.007)$ and phosphate $(\mathrm{F}=7.05$, $\mathrm{P}<0.001)$ (Table 1). The first three PCA axes retained by the broken-stick criterion accounted for $66 \%$ of the total variance. In the first PClaxis ( $\%$ total variance $=$ $29.8 \%$ ), the highest values were observed for conductivity, suspended organic matter, total suspended matter, and chlorophyll (eigenvector coefficients $=-0.38,-0.35$, -0.34 and 0.36 , respectively). For PC2 (\% total variance $=21.2 \%$ ), higher values were identified for dissolved oxygen and temperature (-0.42 and 0.36 respectively), whereas for PC3 (\% total variance $=14.1 \%)$, the highest values were observed for ammonia, total phosphorus and dissolved oxygen $(-0.43,-0.41$ and 0.08 , respectively).
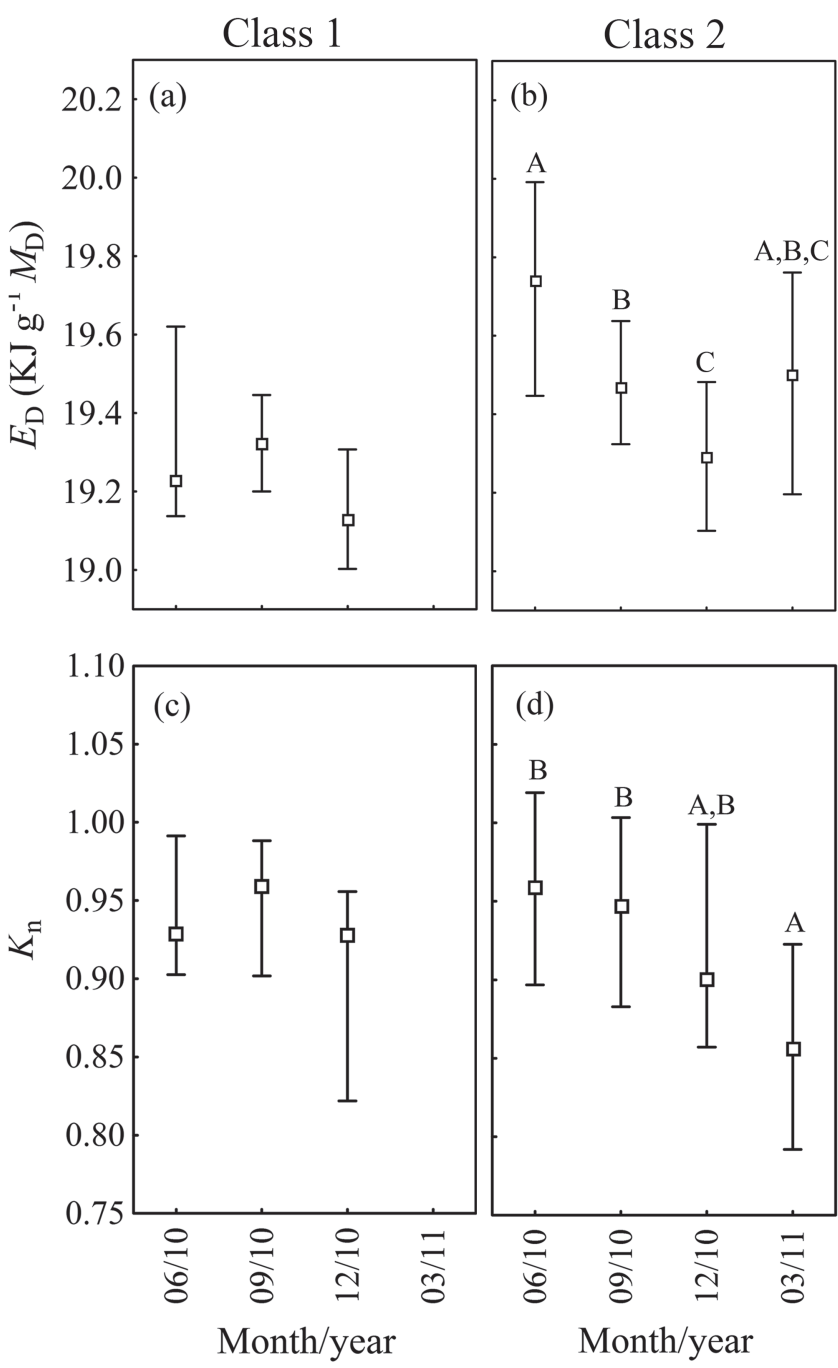

Fig. 4. Median values of energy density $\left(E_{\mathrm{D}}\right)[(\mathrm{a})$, (b)] and the relative condition factor $\left(K_{\mathrm{n}}\right)[(\mathrm{c}),(\mathrm{d})]$, by standard length, in the floodplain of the Upper Paraná River, for each month sampled. Lower bars indicate the $25 \%$ percentile, upper bars indicate the $75 \%$ percentile. Different upper-case letters (ABC) indicate statistically significant differences (Kruskal-Wallis, $P<0.025$ ).
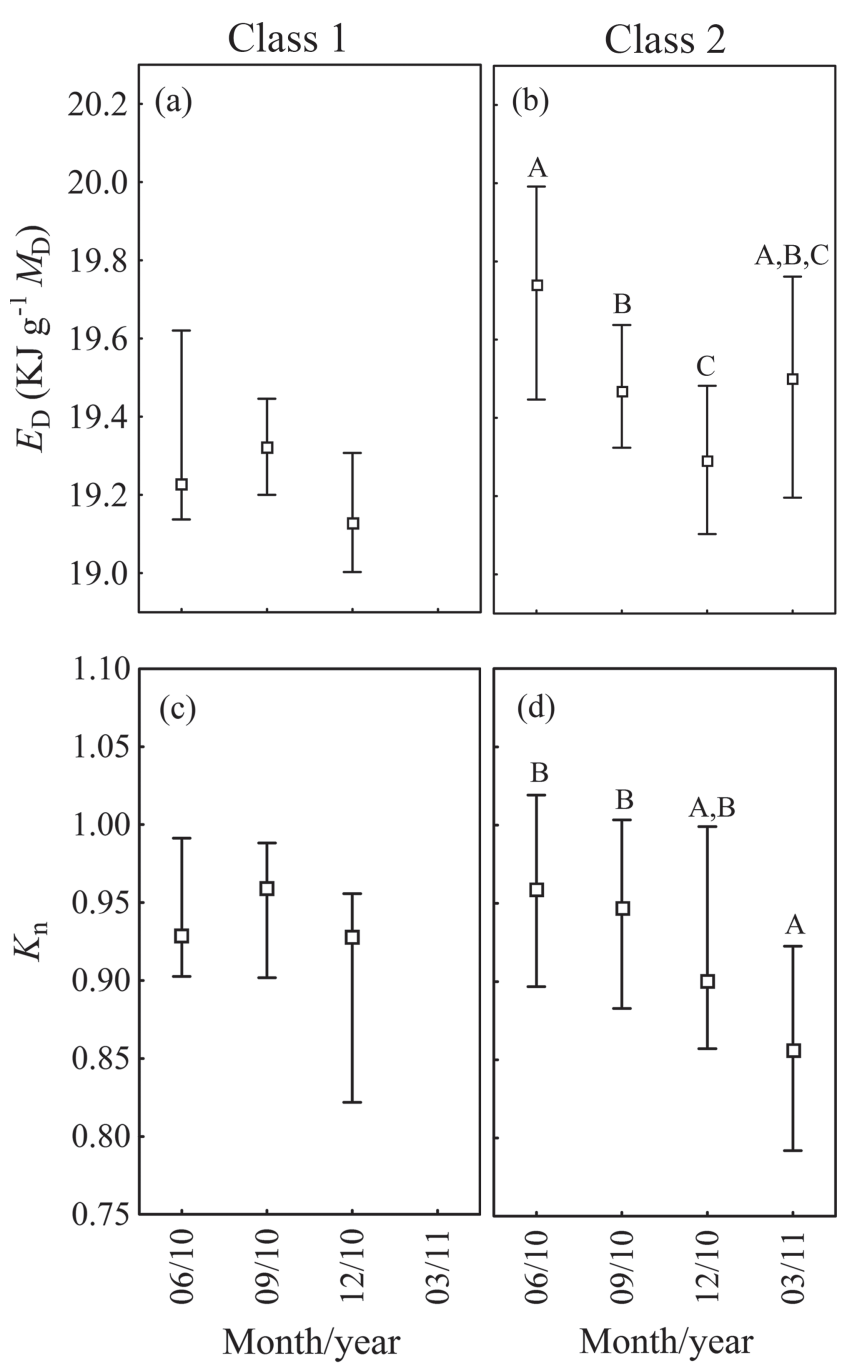

Fig. 5. Median values of energy density $\left(E_{\mathrm{D}}\right)[(\mathrm{a}),(\mathrm{b})]$ and the relative condition factor $\left(K_{\mathrm{n}}\right)[(\mathrm{c}),(\mathrm{d})]$, by standard length, for each sub-basin of the floodplain of the Upper Paraná River - Baia sub-basins (Bai), Ivinhema (Ivi) and Paraná (Par) - from June 2010 to March 2011. Lower bars indicate the $25 \%$ percentile, upper bars indicate the $75 \%$ percentile. Different upper-case letters (ABC) indicate statistically significant differences (Kruskal-Wallis, $P<0.025$ ).

A significant correlation for period (months) was not verified for the PCA axis. For sub-basins, a significant correlation was observed only for condition factor $\left(K_{\mathrm{n}}\right)$, where it was related with the limnological variables from axis 3 in the Paraná sub-basin $(r s=-0.82, P<0.05)$ and with those from axis 1 in the Baia sub-basin $(r s=0: 53, P<0.05)$.

The multiple regression analyses for $E_{\mathrm{D}}$ (adjusted $R^{2}$ $=-0052, P=0.75)$ and $K_{\mathrm{n}}$ (adjusted $R^{2}=0.028, P=0.28$ ), using the variable axis 1 , indicated that the regression model obtained was not significant $\left(R^{2}\right.$ adjusted $\left.=0.871, P=0.055\right)$.

A significant correlation was found between energy density $\left(E_{\mathrm{D}}\right)$ and relative condition factor $\left(K_{\mathrm{n}}\right)\left(r_{\mathrm{s}}=0.24, P<\right.$ $0.05)$, standard length $\left(r_{\mathrm{s}}=0.21, P<0.05\right)$ and total weight (0.29, $P<0.05)$ (Fig. 6). 

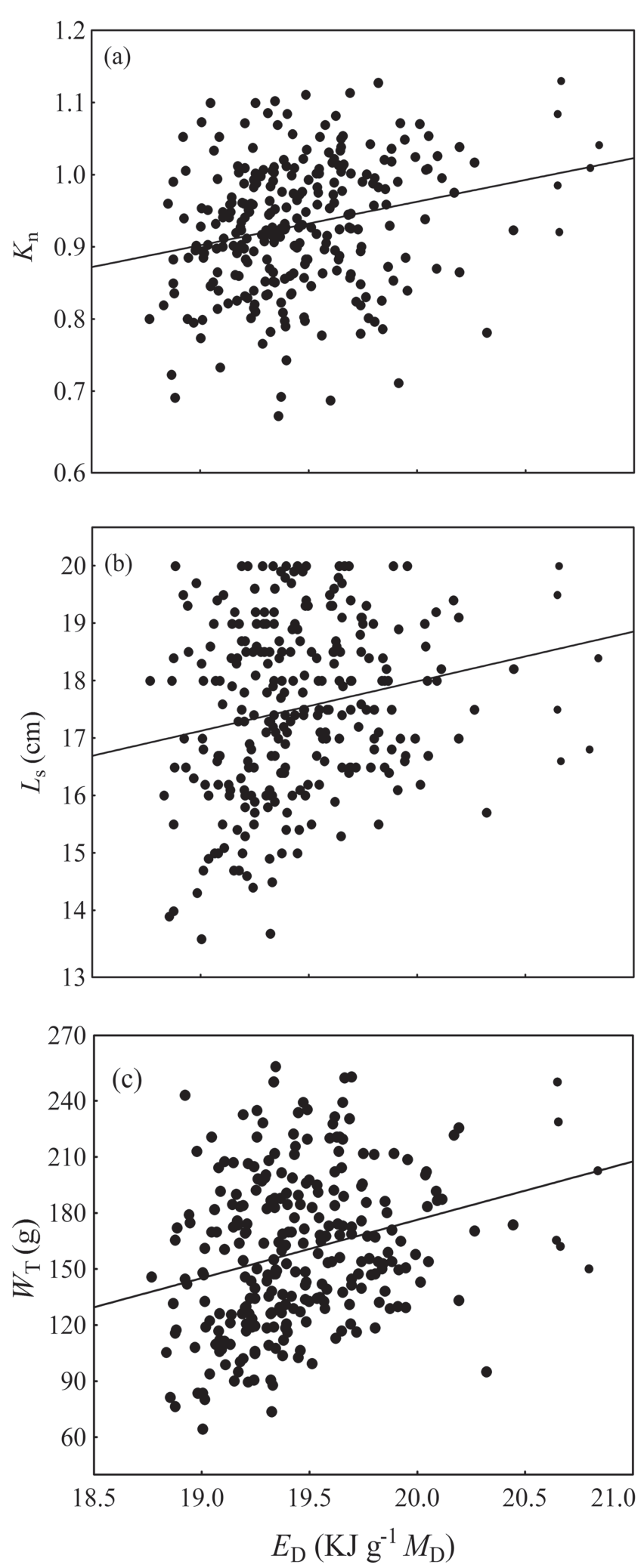

Fig. 6. Spearman rank correlations (rs) between the values of energy density $\left(E_{\mathrm{D}}\right)$ versus relative condition factor $\left(K_{\mathrm{n}}\right)$ (a), length standard $\left(L_{\mathrm{s}}\right)$ (b) and weight total $\left(W_{\mathrm{t}}\right)$ (c) of Prochilodus lineatus in the floodplain of the Upper Paraná River. The line represents the trend of significant Spearman correlations.

\section{Discussion}

Energy density and condition factor have been used as tools to investigate the physiological status of fish in prevailing environmental conditions. On a temporal and spatial scale, the variation in energy density and relative condition factor were mainly related to the limnological effects. However, the energy density and physiological condition factor are parameters resulting from environmental conditions prior to sampling, which do not allow a direct interpretation. This is reflected in the absence of a seasonal correlation between environmental variables and energy density values or condition factor.

In periodically flooded environments, such as the river floodplain system of the Upper Paraná River, the input of allochthonous material into the water increases as the river level rises (Pagioro \& Thomaz, 1999). When the flood recedes, there remains a greater availability of organic debris from the decomposition of flooded terrestrial vegetation transported by the flood and retained in the roots and other parts of macrophytes or from river bottom sediment (Resende et al., 1996). Nevertheless, this process leads to an improvement in feeding conditions and available food sources for $P$. lineatus juveniles. However, the production of periphyton in the floodplains was reported as higher in receding waters and during drought periods (Taniguchi et al., 2005; Algarte et al., 2006; Carapurnarla et al., 2014) or in the Winter (Camargo \& Ferragut, 2014), which also favors the bioavailability for this species.

The gradual reduction mainly in the values of energy density during the first three samplings, in class 2 , can be related to the lack of inputs to the water column, which consequently generates nutritionally and energetically poor sediment and detritus and results in lower values of organic and total suspended matter found in December. The ongoing degradation of materials deposited from a previous flood gradually restricts the dietary conditions of the species that feed on detritus (Bowen, 1983; Chimney \& Pietro, 2006).

The highest values of ammonia, total phosphorus and turbidity were also recorded in December. According to Abujanra et al. (2009), the highest nutrient availability in the water column in the Upper Paraná River floodplain was in low water. In the December 2010 sampling of our study, the water level remained low and the available nutrients may have resulted from the prolonged process of decomposition and release from the same sediment (Lee \& Bukaveckas, 2002; Yahdjian et al., 2006; Schönbrunner et al., 2012). Thus, local processes such as the resuspension of bottom sediments caused by the wind (Evans, 1994; Rodrigues et al., 2002) and disturbance from fish action, may contribute to the increase in nutrients in the water column (Breukelaar et al., 1994).

The availability of periphyton was unclear during the sampling periods, and despite the availability of nutrients, 
turbidity might have influenced periphyton biomass due to a lower penetration of radiation into the water column in December. Camargo \& Ferragut (2014) found that periphyton biomass and algal density in a shallow tropical reservoir were negatively correlated with macrophyte cover and phytoplankton chlorophyll-a, where the availability of nutrients in the water appeared to be less important to community organization. Therefore, studies on the association between detritivorous populations and the periphyton community are necessary.

Although an improved body condition of juveniles during the flood period was observed by Gomes \& Agostinho (1997), this was not observed in the present study in which a non-significant increase in energy density values was observed in March. According to Bevelhimer \& Breck (2009), fish energy content depends on the energy values of the component tissues, and fish in better condition generally have higher lipid levels, which translates into higher energy density. An improvement in the energetic condition of the food availability may have allowed more energy to be released and directed towards metabolism and growth, resulting in an increase in muscle-energy density. Low condition factor values observed during this period might be due to several factors, such as the sampling period occurring at the beginning of the flood period when the food conditions were not sufficiently improved to permit energy reserves for weight increases. It is also possible that the nutritional improvement of the food had not yet led to a weight gain by the beginning of the flood period. Thus, the condition factor values appear to be more resilient to fluctuations in environmental conditions than the energy values. Sacramento et al. (2016), who studied juveniles of $P$. lineatus, confirmed that the turnover of diets in tissues of this species is longer than 100 days. Therefore, our results require confirmation by additional studies that include sampling flood periods, because the deficiencies in sampling during a particular period might have limited the observation of this pattern.

The graphical depiction of the seasonal analysis revealed different patterns for condition factor values and energy density. However, the energy density variation patterns and condition factor were similar by spatial analysis. Spatially, the variation in energy density and condition factor were related to the characteristics of each sub-basin and the degree of conservation. The change caused by damming might explain the significant high values of muscle energy density and condition factor in Ivinhema and the significantly lower values in the Paraná sub-basin. Before the formation of the Porto Primavera Reservoir in the main channel of the Paraná River, the body condition of fish found in the Paraná, Baia and Ivinhema sub-basins varied similarly. However, there was a reduction in the condition factor of fish after completion of this impoundment, especially in the Paraná sub-basin, which was directly affected by the reservoir (Abujanra et al., 2009; Roberto et al., 2009).
Furthermore, the impoundment caused a decrease in the diversity of organisms (Agostinho et al., 2004a; Karling et $a l ., 2013$ ) and a reduction in migratory fish stocks that are important to the fisheries industry (Agostinho et al., 2003; Agostinho et al., 2007), including P. lineatus (Schork et al., 2012). The study area has been impacted by a cascade of upstream reservoirs, which promote the retention of nutrients and sediments (Gimenes et al., 2004; Agostinho et al., 2008) and directly affect the feeding grounds of $P$. lineatus. This results in the lowest values of chlorophyll, turbidity, and total phosphorus, and the highest values of conductivity, organic suspended matter, total suspended matter and nitrate in the Paraná sub-basin. Similar values have been confirmed for chlorophyll, turbidity, and total phosphorus by Roberto et al. (2009) after 20 years of studying the main channel of the Paraná River. The highest values of conductivity, organic suspended matter, total suspended matter and nitrate observed can result from anthropogenic input from land use including agriculture and cattle farming, in addition to urban runoff. The availability of food resources, as well as their energy and condition factor for the fish fauna, are directly related to the dynamics of the sub-basins.

Fish energy density can have a large effect on growth rate, survival and reproduction. For the same level of consumption, fish in good condition had a greater rate of growth in length than fish in poor condition (Bevelhimer \& Breck, 2009). Fish in poor condition allocate more of their new tissue to improving conditions and consequently grow less in length than fish in good condition (Bajer \& Hayward, 2006). Therefore, the absence of impoundments influencing the Ivinhema sub-basin within the "Várzeas do Rio Ivinhema" State Park (MS) protects part of the basin from human impact and contributes to a better condition of this species fish, which was reflected by the observed values of energy density and condition factor, contributing to the integrity of the sub-basin.

The low correlation between the condition factor and energy density is explained by the fact that the increase in weight is dependent on a sufficient amount of intake and time energy allocation to reflect in tissue and energy gain. This balance results in a significant increase in condition factor, and thus the increase in energy density may not reflect in improved body condition through the condition factor (Enrich-Prast \& Esteves, 2005; Espínola et al., 2012). The paramters of condition factor and energy density present different patterns of variation, suggesting that their values could indicate different physiological conditions. A significant correlation between these two parameters was not observed in the analysis of other species (Santos et al., 2006; Garcia \& Benedito, 2010), suggesting the importance of jointly verifying the results from these two parameters, as complementary tools. Although both parameters are directly related to food, they do not always respond similarly to environmental 
variations. Further, the low correlation found between energy density and fish length or weight may have been a reflection of the small size range of individuals. Smaller fish have a lower energy density compared to older and larger fish (Bevelhimer \& Breck, 2009).

Therefore, although the analysis of juvenile fish minimizes the effect of reproducing the energy density in the muscle, the use of size classes is suitable for this parameter, because there is a variation in energy during growth. Although the energy density and the condition factor were not similar for juveniles in some of the analyses, the results from including both parameters provides additional information, enabling a more accurate investigation of the dynamic temporal and spatial processes in Neotropical floodplains, and human interference on the populations of fishes. Even though the specimens from the Paraná sub-basin showed the lowest values of $\mathrm{K}_{\mathrm{n}}$ and $\mathrm{E}_{\mathrm{D}}$ (promoted from the reservoir cascade), the increase in fluviometric levels in different sub-basins of the Upper Paraná River floodplain positively influenced the body condition and energy density of juveniles belonging to detritivorous fish species. This is due to the allocthonous input into the floodplain ecosystem. Because this effect is not immediate and is posteriorly reflected, new studies are required to identify the turnover ratio of energy in tissue and growth of organisms in nature. We suggest that the impacts of this modification should be mitigated or avoided in order to mantain fish stocks and promote ecosystem integrity.

\section{Acknowledgements}

The authors thank Cnpq/Capes/UEM and the PostGraduate Course in Biologia Comparada (PGB-UEM) for financial and logistic support. We also thank all our colleagues for help in the laboratory, and Jaime L. Pereira for preparing the map.

\section{References}

Abujanra, F., A. A. Agostinho \& N. S. Hahn. 2009. Effects of the flood regime on the body condition of fish of different trophic guilds in the Upper Paraná River floodplain, Brazil. Brazilian Journal of Biology, 69(S2): 469-479.

Adams, S. M. \& J. E. Breck. 1990. Bioenergetics. Pp. 389-415. In: Schreck, C. B. \& P. B. Moyle (Eds.). Methods for Fish Biology. Bethesda, American Fisheries Society.

Adams, S. M., R. B. McLean \& J. A. Parrotta. 1982. Energy partitioning in Largemouth Bass under conditions of seasonally fluctuating prey availability. Transactions of the American Fisheries Society, 111: 549-558.

Agostinho, A. A., A. E. A. de M. Vazzoler, L. C. Gomes \& E. K. Okada. 1993. Estratificación espacial y comportamiento de Prochilodus scrofa en distintas fases del ciclo de vida, en la planície de inundación del alto rio Parana y embalse de Itaipu, Paraná, Brasil. Revue D’Hydrobiologie Tropicale 26: 79-90.
Agostinho, A. A., F. M. Pelicice \& L. C. Gomes. 2008. Dams and the fish fauna of the Neotropical region: impacts and management related to diversity and fisheries. Brazilian Journal of Biology, 68 (S4): 1119-1132.

Agostinho, A. A., L. C. Gomes, H. I. Suzuki \& H. F. Júlio Júniorr. 2003. Migratory fishes of the Upper Parana River Basin, Brazil. Pp. 19-99. In: Carolsfeld, J., B. Harvey, C. Ross \& A. Baer (Eds.). Migratory Fishes of South America: Biology, Fisheries and Conservation Status. Victoria, World Fisheries Trust.

Agostinho A. A., S. M. Thomaz \& L. C. Gomes. 2004a. Threats for biodiversity in the floodplain of the Upper Paraná River: effects of hydrological regulation by dams. Ecohydrology \& Hydrobiology, 4: 255-268.

Agostinho, A. A., L. C. Gomes, S. Veríssimo \& E. K. Okada. $2004 b$. Flood regime, dam regulation and fish in the Upper Paraná River: effects on assemblage attributes, reproduction and recruitment. Reviews in Fish Biology and Fisheries, 14: 11-19.

Agostinho, A. A., F. M. Pelicice, A. C. Petry, L. C. Gomes. \& H. F. Júlio Júnior. 2007. Fish diversity in the Upper Paraná River basin: habitats, fisheries, management and conservation. Aquatic Ecosystem Health \& Management, 10: 174-186.

Algarte, V. M., C. Moresco \& L. Rodrigues. 2006. Algas do perifíton de distintos ambientes na planície de inundação do alto rio Paraná. Acta Scientiarum, Biological Sciences, 28: 243-251.

Bajer, P. G. \& R. S. Hayward. 2006. A combined multipleregression and bioenergetics model for simulating fish growth in length and condition. Transactions of the American Fisheries Society, 135: 695-710.

Barbieri, G., F. A. Sales, \& M. A. Cestarolli. 2000. Influência de fatores abióticos na reprodução do dourado, Salminus maxillosus e do curimbatá, Prochilodus lineatus do rio Mogi Guaçu (Cachoeira de Emas, Pirassununga/SP). Acta Limnologica Brasiliensia, 12: 85-91.

Bayo, V. \& E. C. Yuan. 1996. Food assimilation of a neotropical riverine detritivorous fish, Prochilodus lineatus, studied by fatty acid composition (Pisces, Curimatidae). Hydrobiologia, 330: 81-88.

Bevelhimer, M. S. \& J. E. Breck. 2009. Centrarchid Energetics. Pp. 165-206 In: Cooke, S. J. \& D. P. Philipp (Eds.). Centrarchid Fishes: Diversity, Biology and Conservation, Oxford, WileyBlackwell.

Block, W. M., A. B. Franklin, J. P. Ward Jr., J. L. Ganey \& G. C. White. 2001. Design and implementation of monitoring studies to evaluate the success of ecological restoration on wildlife. Restoration Ecology, 9: 293-303.

Bowen, S. H. 1983. Detritivory in neotropical fish communities. Environmental Biology of Fishes, 9: 137-144.

Bozza, A. N. \& N. S. Hahn. 2010. Uso de recursos alimentares por peixes imaturos e adultos de espécies piscívoras em uma planície de inundação neotropical. Biota Neotropica, 10: 217-226.

Breukelaar, A. W., E. H. R. R. Lammens, J. G. P. K. Breteler \& I. Tátrai. 1994. Effects of benthivorous bream (Abramis brama) and carp (Cyprinus carpio) on sediment resuspension and concentrations of nutrients and chlorophyll a. Freshwater Biology, 32: 113-121. 
Camargo, V. M. \& C. Ferragut. 2014. Estrutura da comunidade de algas perifíticas em Eleocharis acutangula (Roxb.) Schult (Cyperaceae) em reservatório tropical raso, São Paulo, SP, Brasil. Hoehnea, 41: 31-40.

Carapurnala, L., D. Baumgartner \& L. Rodrigues. 2014. Community structure of periphytic algae in a floodplain lake: a longterm study. Acta Scientiarum, Biological Sciences, 36: 147-154.

Chimney, M. J. \& K. C. Pietro. 2006. Decomposition of macrophyte litter in a subtropical constructed wetland in south Florida (USA). Ecological Engineering, 27: 301-321.

Cui, Y. \& R. J. Wootton. 1988. Effects of ration, temperature and body size on the body composition, energy content and condition of the minnow Phoxinus phoxinus (L.). Jounal of Fish Biolology, 32: 749-764.

Dourado, E. C. S. \& E. Benedito-Cecilio. 2005. Ecologia Energética de peixes: influência de fatores abióticos e bióticos. Maringá, EDUEM, 53p.

Enrich-Prast, A. \& F. A. Esteves. 2005. Flood pulse influence and anthropic impact on the chemical composition and energy content of Oryza glumaepatula in the Amazonian lake. Brazilian Jounal of Biology, 65: 451-458.

Espínola, L. A., E. A. P. Santos, W. M. Domingues \& E. Benedito. 2010. Conteúdo calórico de músculos de Prochilodus lineatus (Characiformes, Prochilodontidae) no reservatório de Manso, Brasil. Interciência, 35: 445-449.

Espínola, L. A., H. F. Júlio Júnior \& E. Benedito. 2012. Invasive non-native species of fish in upper Paraná river Basin, Brazil: variations of caloric content in Cichla kelberi. Neotropical Ichthyology, 10: 401-408

Evans, R. D. 1994. Empirical evidence of the importance of sediment resuspension in lakes. Hydrobiologia, 284: 5-12.

Froese, R. 2006. Cube law, condition factor and weight-length relationships: history, meta-analysis and recommendations. Journal of Applied Ichthyology, 22: 241-253.

Froese, R. \& D. Pauly (Eds.). 2015. FishBase. Available from: http://www.fishbase.org, version (10 January 2015).

García-Berthou, E. 2001. On the misuse of residuals in ecology: testing regression residuals vs. the analysis of covariance. Journal of Animal Ecology, 70: 708-711.

Garcia, D. A. \& E. Benedito. 2010. Variation in energy density of Loricariichthys platymetopon (Siluriformes: Loricariidae) in the Upper Paraná River basin. Neotropical Ichthyology, 8: 321-327.

Gimenes, M. F., E. Benedito-Cecilio, A. M. Takeda \& M. R. Vismara. 2004. Availability of sedimentary organic matter for benthic fishes of the Upper Paraná river floodplain. Acta Scientiarum, Biological Sciences, 26: 181-187.

Godoy, M. P. 1975. Peixes do Brasil: subordem Characoidei, Bacia do rio Mogi Guassu. Piracicaba, Franciscana press, 846p.

Gomes, L. C. \& A. A. Agostinho. 1997. Influence of the flooding regime on the nutricional state and juvenile recruitment of the curimba, Prochilodus scrofa, Steidachner, in upper Paraná River, Brazil. Fisheries Management and Ecology, 4: 263-274.

Graça, W. J. \& C. S. Pavanelli. 2007. Peixes da planície de inundação do alto rio Paraná e áreas adjacentes. Maringá, EDUEM, 241p.
Hahn, N. S., I. F. Andrian, R. Fugi \& V. L. L. Almeida. 1997. Ecologia trófica. Pp. 209-228. In: Vazzoler, A. E. A. M., A. A. Agostinho \& N. S. Hahn (Eds.). A planície de inundação do alto rio Paraná: aspectos físicos, biológicos e sócioeconômicos. Maringá, EDUEM.

Hahn, N. S., R. Fugi \& I. F. Andrian. 2004. Trophic ecology of the fish assemblages. Pp. 247-269. In: Thomaz, S. M., A. A. Agostinho \& N. S. Hahn (Eds.). Upper Paraná River and its Floodplain: physical aspects, ecology and conservation. Leiden, Backhuys Publishers.

Herbinger, C. M. \& G. W. Friars. 1991. Correlation between condition factor and total lipid content in Atlantic salmon, Salmon salar L., Parr. Aquaculture and Fisheries Management, 22: 527-529.

Junk, W. J., P. B. Bayley \& R. E. Sparks. 1989. The flood pulse concept in river-floodplain systems. Pp. 110-127. In: Dodge, D. P. (Ed.). Proceedings of the International Large River Symposium. Canadian Special Publication of Fisheries and Aquatic Sciences.

Karling L. C., A. Isaac, I. P. Affonso, R. M. Takemoto \& G. C. Pavanelli. 2013. The impact of a dam on the helminth fauna and health of a neotropical fish species Salminus brasiliensis (Cuvier, 1816) from the Upper Paraná River, Brazil. Journal of Helminthology, 87: 245-251.

Le Cren, E. D. 1951. The length-weight relationship and seasonal cycle in gonad weight and condition in the perch (Perca fluviatis). Journal of Animal Ecology, 20: 201-219.

Leandrini, J. A., I. A. Fonseca \& L. Rodrigues. 2008. Characterization of habitats based on algal periphyton biomass in the Upper Paraná River floodplain, Brazil. Brazilian Jounal of Biology, 68: 503-509.

Lee, A. A. \& P. A. Bukaveckas. 2002. Surface cwater nutrient oncentrations and litter decomposition rates in wetlands impacted by agriculture and mining activities. Aquatic Botany, 74: 273-85.

Lindeman, R. L. 1942. The trophic-dynamic aspect of ecology. Ecology, 23: 399-418.

Luz-Agostinho, K. D. G., A. A. Agostinho, L. C. Gomes \& H. F. Júlio Júnior. 2008. Influence of flood pulses on diet composition and trophic relationships among piscivorous fish in the upper Paraná River floodplain. Hydrobiologia, 607: 187-198.

Monteiro V., E. Benedito \& W. M. Domingues. 2007. Efeito da estratégia de vida sobre as variações no conteúdo de energia de duas espécies de peixes (Brycon hilarii e Hypophthalmus edentatus), durante o ciclo reprodutivo. Acta Scientiarum, Biological Sciences, 29: 151-159.

Neiff, J. J. 2001. Biodiversity in some tropical wetlands systems of South America. Pp. 157-186. In: Gopal, B., W. J. Junk \& J. A. Davis (Eds.) Biodiversity in wetlands: assessment, function and conservation. Leiden, Backhuys Publishers.

Oliveira A. G, H. I. Suzuki, L. C. Gomes \& A. A. Agostinho. 2015. Interspecific variation in migratory fish recruitment in the Upper Paraná River: effects of the duration and timing of floods. Environmental Biology of Fishes, 98: 1327-1337. 
Pagioro, T. A. \& S. M. Thomaz. 1999. Decomposition of Eichhornia azurea from limnologically different environments of the Upper Paraná River floodplain. Hydrobiologia, 411: 45-51.

Petrere Júnior., M. 1996. Fisheries in large tropical reservoirs in South America. Lakes \& Reservoirs: Research and Management, 2: 111-133.

Resende, E. K., A. C. Catella, F. L. Nascimento, S. S. Palmeira, R. A. C. Pereira, M. S. Lima \& V. L. L. Almeida. 1996. Biologia do curimbatá (Prochilodus lineatus), pintado (Pseudoplatystoma corruscans) e cachara (Pseudoplatystoma fasciatum) na bacia hidrográfica do rio Miranda, Pantanal do Mato Grosso do Sul, Brasil. Corumbá, EMBRAPA-CPAP, 75p.

Roberto, M. C., N. F. Santana \& S. M. Thomaz. 2009. Limnology in the Upper Paraná River floodplain: large-scale spatial and temporal patterns, and the influence of reservoirs. Brazilian Journal of Biology, 69(S2): 717-725.

Rodrigues, L. C., S. Train, M. C. Roberto \& T. A. Pagioro. 2002. Seasonal fluctuation of some limnological variables on a floodplain lake (Patos Lagoon) of the Upper Paraná River, Mato Grosso Do Sul state, Brazil. Brazilian Archives of Biology and Technology, 45: 499-513.

Sacramento, P. A, G. I. Manetta \& E. Benedito. 2016. Diet-tissue discrimination factors $\left(\Delta^{13} \mathrm{C}\right.$ and $\left.\Delta^{15} \mathrm{~N}\right)$ and turnover rate in somatic tissues of a Neotropical detritivorous fish on $\mathrm{C} 3$ and C4 diets. Journal of Fish Biology, 89: 213-219.

Saldaña, J. \& B. Venables. 1983. Energy compartmentalization in a migratory fish, Prochilodus mariae (Prochilodontidae), of the Orinoco river. Copeia, 3: 617-623.

Santos, A. F. G. N., L. N. Santos \& F. G. Araújo. 2004. Water level influences on body condition of Geophagus brasiliensis (Perciformes: Cichlidae) in a Brazilian oligotrophic reservoir. Neotropical Ichthyology, 2: 151-156.

Santos, M. H. dos, E. Benedito \& W. M. Domingues. 2006. Efeito da maturação gonadal sobre a energia dos músculos de duas espécies de piranhas do reservatório do rio Manso, Estado de Mato Grosso. Acta Scientiarum, Biological Sciences, 28: 227236.

Schönbrunner, I. M., S. Preiner \& Thomas Hein. 2012. Impact of drying and re-flooding of sediment on phosphorus dynamics of river-floodplain systems. Science of The Total Environment, 432: 329-337.

Schork, G., S. Hermes-Silva, L. F. Beux, E. Zaniboni-Filho \& A. P. O. Nuñer. 2012. Diagnóstico da pesca artesanal na usina hidrelétrica de Machadinho, alto rio Uruguai - Brasil. Boletim do Instituto da Pesca, 38: 97-108.
Silva, E. M., V. Gonçalves E. M. Silva \& A. C. Murolo. 1999. Estatística para os cursos de: Economia, Administração e Ciências Contábeis. São Paulo, Atlas, 189p.

Sivasundar, A., E. Bermingham, \& G. Ortí. 2001. Population structure and biogeography of migratory freshwater fishes (Prochilodus: Characiformes) in major South American rivers. Molecular Ecology, 10: 407-417.

Sokal, R. R \& F. J. Rohlf. 1995. Biometry: the principles and practice of statistics in biological research. New York, W. H. Freeman and Company, 887p.

Suzuki, H. I., A. E. A. M. Vazzoler, E. E. Marques, M. A. P. Lizama \& P. Inada. 2004. Reproductive ecology of the fish assemblage. Pp. 271-292. In: Thomaz, S. M., A. A. Agostinho \& N. S. Hahn (Orgs.). The Upper Paraná River and its floodplain: physical aspects, ecology and conservation. Leiden, Backhuys Publishers.

Taniguchi, G. M., D. C. Bicudo \& P. A. C. Senna. 2005. Gradiente litorâneo-limnético do fitoplâncton e ficoperifíton em uma lagoa da planície de inundação do Rio Mogi-Guaçu. Revista Brasileira de Botânica, 28: 137-147.

Thomaz S. M., L. M. Bini \& R. L. Bozelli. 2007. Floods increase similarity among aquatic habitats in river-floodplain systems. Hydrobiologia, 579: 1-13.

Thomaz, S. M., T. A. Pagioro, L. M. Bini, M. C. Roberto \& R. R. A. Rocha. 2004. Limnological characterization of the aquatic environments and the influence of hydrometric levels. Pp. 75102. In: Thomaz, S. M., A. A. Agostinho \& N. S. Hahn (Eds.). The Upper Paraná River and its Floodplain: physical aspects, ecology and conservation. Leiden, Backhuys Publishers.

Vanzolini, P. E. 1993. Métodos estatísticos elementares em sistemática zoológica. São Paulo, HUCITEC, 130p.

Vazzoler, A. E. A. M. 1996. Biologia da Reprodução de Peixes Teleósteos: Teoria e Prática. Maringá, EDUEM.

Yahdjian, L., O. E. Sala \& A. T. Austin. 2006. Differential Controls of Water Input on Litter Decomposition and Nitrogen Dynamics in the Patagonian Steppe. Ecosystems, 9: 128-141.

Zar, J. H. 1999. Biostatistical Analysis. Michigan, Pearson Prentice Hall, 944p.
Submitted May 02, 2014 Accepted August 24, 2016 by Paulo Pompeu 
